DOI:10.17951/h.2020.54.3.59-66

\begin{tabular}{lcc}
\hline \multicolumn{3}{c}{ A N N A L E S } \\
UNIVERSITATIS MARIAE CURIE-SKŁODOWSKA \\
LUBLIN - POLONIA \\
VOL. LIV, 3 & SECTIOH H \\
\hline
\end{tabular}

\author{
GABRIELA MATWIEJ \\ gabrielagrzywna@gmail.com \\ Uniwersytet Marii Curie-Skłodowskiej w Lublinie. Wydział Ekonomiczny \\ pl. Marii Skłodowskiej-Curie 5, 20-031 Lublin \\ ORCID ID: https://orcid.org/0000-0003-0195-1257
}

\title{
Dobrostan i satysfakcja z jakości życia zawodowego młodych kobiet. Wyniki badań
}

Well-Being and Satisfaction on the Quality of Professional Life of Young Women. Study Results

Keywords: well-being; satisfaction; professional life; young women

Słowa kluczowe: dobrostan; satysfakcja; życie zawodowe; młode kobiety

JEL: I31; J24

Propozycja cytowania: Matwiej, G. (2020). Dobrostan i satysfakcja z jakości życia zawodowego młodych kobiet. Wyniki badań. Annales Universitatis Mariae Curie-Skłodowska, sectio H-Oeconomia, Vol. 54, No. 3.

\footnotetext{
Abstract

Theoretical background: In recent years, the literature emphasizes the role of employee well-being and work-life balance which are important for the satisfaction of the professional life of employees.

Purpose of the article: Presentation of the level of well-being and satisfaction with the professional life of young women aged 25 to 35 living in the Lublin Voivodeship.

Research methods: Easton and Van Laar survey questionnaire. The study covered 155 women aged 25 to 35 living in the Lublin Voivodeship.

Main findings: The results indicate an average level of satisfaction with working life. The relationship between satisfaction with professional life and having children and the position held was found. In the future, when carrying out research, it is worth considering the nature of the profession performed by women, not just age or having children.
} 


\begin{abstract}
Abstrakt
Uzasadnienie teoretyczne: $\mathrm{W}$ ostatnich latach w literaturze podkreśla się rolę dobrostanu pracowników i równowagi praca-życie, które są istotne dla satysfakcji z życia zawodowego zatrudnionych.

Cel artykułu: Zaprezentowanie poziomu dobrostanu i satysfakcji z życia zawodowego młodych kobiet w wieku od 25 do 35 lat, mieszkających w województwie lubelskim.

Metody badawcze: Kwestionariusz ankiety Easton i Van Laar. Badaniem objęto 155 kobiet w wieku od 25 do 35 lat, mieszkających w województwie lubelskim.

Glówne wnioski: Efekty badań wskazują na średni poziom satysfakcji z życia zawodowego. Stwierdzono związek satysfakcji z życia zawodowego z posiadaniem dzieci oraz zajmowanym stanowiskiem. W przyszłości, wykonując badania, warto wziąć pod uwagę charakter wykonywanego przez kobiety zawodu, a nie tylko wiek czy posiadanie dzieci.
\end{abstract}

\title{
Wprowadzenie
}

W ostatnich latach w literaturze z zakresu zarządzania zasobami ludzkimi podkreśla się znaczenie dobrostanu pracowników i równowagi praca-życie, które są istotne dla satysfakcji z życia zawodowego zatrudnionych. Brak równowagi między życiem zawodowym a prywatnym, czyli trudności z godzeniem obowiązków związanych z pracą i życiem osobistym, negatywnie oddziałuje na dobrostan i satysfakcję z życia zawodowego. Brak równowagi prowadzi do konfliktu między życiem zawodowym a prywatnym (Friedman \& Greenhaus, 2000; Kreiner, Hollensbe, \& Sheep, 2009). W szczególności dotyczy to młodych kobiet, które muszą godzić karierę zawodową z obowiązkami rodzinnymi. Na problem równowagi praca-życie zwróciła uwagę amerykańska badaczka Kanter (1977), która interesuje się wpływem pracy kobiet na rodzinę. Duży wkład ma także Schor (1991) w kontekście debaty na temat równowagi między życiem zawodowym a prywatnym. Jak wynika $\mathrm{z}$ badań, sytuacja zawodowa kobiet w Polsce jest dobra. „The Economist” w 2018 r. umieścił Polskę na siódmym miejscu (na 29 państw) w rankingu krajów, które są przyjazne dla kobiet aktywnych zawodowo. Wciąż jednak interesujące jest poznanie odpowiedzi na pytanie, jak młode kobiety postrzegają swój dobrostan i jakość życia zawodowego. W niniejszym artykule przedstawiono wyniki badań przeprowadzonych na grupie kobiet z wykorzystaniem kwestionariusza ankiety.

\section{Dobrostan i równowaga praca-życie}

W literaturze przedmiotu popularnym określeniem $\mathrm{w}$ ostatnich latach stało się pojęcie well-being, czyli „dobrostan”. Jak podaje WHO (1948), termin ten oznacza stan pełnego fizycznego, psychicznego i społecznego dobrostanu, a nie tylko brak choroby. W Polsce dobrostan jest łączony z satysfakcją z jakości życia zawodowego (Mendryk \& Rakowska, 2016). Zdaniem Niśkiewicz (2016) dobrostan można zdefiniować jako efekt poznawczej i emocjonalnej oceny życia jednostki, na którą składa się spełniona satysfakcja egzystencjonalna. Przejawia się on zadowoleniem, 
szczęściem, pozytywnymi emocjami, które towarzyszą człowiekowi. Dobrostan wiązany jest także z relacjami rodzinnymi i małżeńskimi oraz z pełnionymi rolami społecznymi i zawodowymi (Karaś \& Cieciuch, 2017).

Dobrostan może być również analizowany w kontekście wartości. Zarówno kobiety, jak i mężczyźni mają zbliżone wartości życiowe, ale zmieniają się one na przestrzeni życia, co w przypadku kobiet jest związane z pełnieniem ról rodzicielskich (Major, Morganson, \& Bolen, 2013). Wybór kariery zawodowej przez kobiety zależy od możliwości zachowania równowagi między życiem zawodowym a prywatnym (Rakowska \& Cichorzewska, 2019).

Problem zachowania równowagi praca-życie i związany z tym dobrostan dotyczy pracowników w różnym wieku. Wraz z upływem czasu zmieniają się role życiowe i społeczne, a w związku z tym zmianie ulegają też pełnione obowiązki (Hildt-Ciupińska, 2014). Równowaga między życiem zawodowym a prywatnym jest niezbędna dla kobiet, co może wynikać z pełnionej przez nie roli społecznej. $Z$ badań wynika, że postawa wobec równowagi praca-życie ulega zmianie wraz z wiekiem. Badacze wskazują m.in. na trudności pracowników w zaspokajaniu potrzeb w pracy i poza nią (Carlson, Kacmar, Wayne, \& Grzywacz, 2006). Niektórzy wymieniają również wpływ konfliktu praca-życie na pracę zawodową (w tym na zdolność do pracy, satysfakcję z niej, dobre samopoczucie w pracy, motywację itp.).

Zdaniem Smodera (2012) work-life balance jest zachowany, jeśli człowiek:

- ma możliwość osiągnięcia celów w różnych sferach życia,

- doświadcza satysfakcji we wszystkich obszarach życia,

- zobowiązania zawodowe godzi z obowiązkami rodzinnymi, nauką, zaangażowaniem społecznym, odpoczynkiem,

- dąży do samorealizacji w wielu aspektach życia,

- sferę osobistą i zawodową postrzega jako obszary komplementarne, a nie opozycyjne,

- potrafi właściwie organizować czas, wykorzystuje dostępne wsparcie (ze strony rodziny, współpracowników).

Z badań wynika, że w przypadku kobiet - inaczej niż w przypadku mężczyzn wraz z wiekiem zmienia się znaczenie przypisane równowadze praca-życie (Rakowska \& Cichorzewska, 2019), co wynika w dużej mierze z pełnionych ról społecznych. Dodać należy, że polskie kobiety są bardzo aktywne na rynku pracy, co oznacza, że muszą starać się godzić role społeczne i zawodowe. Dlatego ciekawe jest poznanie odpowiedzi na pytanie, jak oceniają swój dobrostan i satysfakcję z życia zawodowego. W szczególności dotyczy to młodych kobiet, które znajdują się na początku kariery zawodowej i jednocześnie pełnią określone role społeczne. 


\section{Koncepcja jakości życia zawodowego}

Jakość życia zawodowego stała się ostatnio interesującym obszarem badawczym. W literaturze można spotkać się ze stanowiskiem, że jednym z jej wyznaczników jest satysfakcja z pracy. Może być ona rozumiana jako:

- poziom odczuwanego szczęścia, satysfakcji czy zadowolenia z życia,

- zakres realizacji własnych potrzeb i dążeń,

- poziom własnego rozwoju i zadowolenia z życia prywatnego (Krause, Żyta, \& Nosarzewska, 2010),

- zadowolenie z osiągnięć własnych oraz z warunków bytowania (Diener, Emmons, Larsen, \& Griffin, 1985).

Obszar zawodowy jest ściśle związany z satysfakcją z wykonywanego zawodu. Jak podaje Bańka (2000), satysfakcja z pracy ,jest uczuciową reakcją przyjemności lub przykrości, doznawanej w związku z wykonywaniem określonych zadań, funkcji oraz ról".

Warto dodać, że życie pozazawodowe również ma ogromny wpływ na jakość życia zawodowego. Składowe to struktura własnego ,ja”, wiek, życie rodzinne oraz status społeczny. W jakość życia zawodowego wpisuje się też klimat psychologiczny, który wiąże się z postrzeganiem środowiska organizacyjnego, co z kolei oddziałuje na emocje i motywacje pracowników (Wołowska, 2013).

Ciekawą koncepcję ,jakości życia zawodowego" zaproponowali Easton i Van Laar (2012, 2014). Naukowcy ci stworzyli model Jakości Życia Zawodowego, do którego przygotowali kwestionariusz ankiety „Jakość Życia Zawodowego” (WRQoL). Narzędzie to jest przydatne w wielu organizacjach na całym świecie. Wspomniani badacze uważają, że odczucia dotyczące jakości życia zawodowego w dużej mierze zależą od indywidualnych doświadczeń w pracy oraz czynników, które mają na to wpływ. Osobiste predyspozycje, ogólny dobrostan i warunki pracy oddziałują na to, jak dana osoba zachowuje się w miejscu pracy i co do niej wnosi. Worrall i Cooper (2006) zauważyli, że lepsza jakość pracy niesie za sobą wiele korzyści dla jednostki i organizacji. Co ważne, dowiedli m.in. istnienie związków między jakością życia zawodowego a spadkiem absencji chorobowej, co w konsekwencji prowadzi do wzrostu przychodów firmy. Niski poziom dobrego samopoczucia w pracy może kosztować około 5-10\% produktu narodowego brutto rocznie, dlatego warto badać poziom satysfakcji z życia zawodowego pracowników.

\section{Metodyka badań}

Celem badań było zidentyfikowanie poziomu zadowolenia zjakości życia zawodowego młodych pracujących kobiet w wieku od 25 do 35 lat z województwa lubelskiego. Do realizacji celu wykorzystano kwestionariusz ankiety opracowany przez Eastona i Van Laara (2018). W literaturze można odnaleźć kilka pozycji odnoszących się do 
tej problematyki. Kanter (1977), Schor (1991) oraz Major, Morganson i Bolen (2013) w swoich publikacjach nawiązują do związku między posiadaniem dzieci a oceną jakości życia zawodowego i postaw z tym związanych. Drzeżdżon (2006) zaś uważa, że jakość pracy zawodowej w istotnym stopniu decyduje o ogólnej jakości życia.

Sformułowano następujące pytania badawcze:

1. Czy istnieje związek między stanowiskiem a oceną jakości życia zawodowego w kontekście poszczególnych sześciu skal?

2. Czy istnieje związek między posiadaniem dzieci a oceną jakości życia zawodowego w kontekście poszczególnych sześciu skal?

Narzędzie badawcze. Do badania wykorzystano kwestionariusz ankiety z sześcioma skalami Eastona i Van Laara (2018).

Ogólne samopoczucie (GWB). Skala ta obejmuje szerszy aspekt samopoczucia psychicznego oraz ogólne zdrowie fizyczne. Samopoczucie psychiczne może wpływać na wydajność danej osoby w pracy (trzy pytania).

Równowaga między pracą a życiem prywatnym (HWI). Skala work-life balance pozwala ocenić, w jakim stopniu pracownicy czują, że mają kontrolę nad tym, kiedy, gdzie i jak działają (trzy pytania). Jest ona szczególnie ważna dla młodych kobiet (Rakowska \& Cichorzewska, 2019).

Satysfakcja z pracy i kariery zawodowej (JCS). Skala JCS prezentuje poziom satysfakcji, jaki miejsce pracy zapewnia osobie zatrudnionej. Wskazuje też na to, co sprawia, że czują się dobrze: poczucie spełnienia, wysoka samoocena i realizacja potencjału. Współczynnik ten jest związany z warunkami pracy (WKS) w ramach modelu QoWL (sześć pytań).

Kontrola w pracy (CAW). Postrzeganie kontroli może być związane z różnymi aspektami pracy, w tym z możliwością przyczynienia się do procesu podejmowania decyzji, które dotyczą pracowników (trzy pytania).

Warunki pracy (WCS). Skala obejmuje zadowolenie z podstawowych zasobów, warunków i bezpieczeństwa pracy, niezbędnych do skutecznego wykonywania swoich zadań (trzy pytania).

Stres w pracy (SAW). Stres w pracy jest szkodliwą reakcją fizyczną i emocjonalną, występującą, gdy wymagania pracy są wyższe niż możliwości, zasoby i potrzeby pracownika. Czynnik ten zawiera dwa pytania, a jego skala była odwrócona.

\section{Charakterystyka próby badawczej}

Dobór próby badawczej miał charakter celowy. Do badania zaproszono młode i pracujące kobiety w wieku od 25 do 35 lat. Zastosowano metodę kuli śnieżnej. Kwestionariusz ankiety umieszczono na platformie gmail, gdzie był on anonimowo wypełniany. Ostatecznie w ankiecie udział wzięło 155 kobiet, w tym $49 \%$ respondentek zajmowało stanowisko wykonawcze, $43 \%$ - specjalistyczne, a $8 \%$ - kierownicze. Ponadto $60 \%$ ankietowanych nie posiada dzieci, a $40 \%$ - posiada. 


\section{Wyniki badań}

W tabeli 1 zamieszczono ogólne wyniki badań, tj. średnie arytmetyczne dotyczące poszczególnych wymiarów jakości życia zawodowego respondentek.

Tabela 1. Wyniki badań

\begin{tabular}{|c|c|c|c|c|c|}
\hline Dobrostan & Równowaga praca-życie & Satysfakcja z pracy, kariery & Kontrola & Warunki pracy & Stres (R) \\
\hline $\mathrm{x}^{-} ; \mathrm{SD}$ & $\mathrm{x}^{-} ; \mathrm{SD}$ & $\mathrm{x}^{-} ; \mathrm{SD}$ & $\mathrm{x}^{-} ; \mathrm{SD}$ & $\mathrm{x}^{-} ; \mathrm{SD}$ & $\mathrm{x}^{-} ; \mathrm{SD}$ \\
\hline \multicolumn{5}{|c|}{ Wyniki badań własnych } \\
\hline 3,$66 ; 0,98$ & 3,$44 ; 1,33$ & 3,$63 ; 1,14$ & 3,$63 ; 1,05$ & 3,$95 ; 1,01$ & 2,$71 ; 1,24$ \\
\hline
\end{tabular}

$\mathrm{x}^{-}$- średnia; SD - odchylenie standardowe; w przypadku stresu skala jest odwrócona

Źródło: opracowanie własne.

Z danych zamieszczonych w tabeli 1 wynika, że najwyżej oceniony wskaźnik to warunki pracy, a zaraz za nim znajduje się odczuwany dobrostan. Respondentki mają mniejszą kontrolę nad równowagą pomiędzy pracą a życiem osobistym. Kontrola w pracy została oceniona na 3,63 (średnia). Zmienna dotycząca stresu występującego w miejscu pracy jest równa 2,71 . Może to wynikać z różnorodności branż, w których pracują ankietowane kobiety.

Wyniki badań dotyczące stanowiska pracy i dzietności znajdują się w tabelach 2 i 3.

Tabela 2. Wyniki według stanowiska pracy

\begin{tabular}{|c|c|c|c|c|c|}
\hline Dobrostan & Równowaga praca-życie & Satysfakcja z pracy, kariery & Kontrola & Warunki pracy & Stres (R) \\
\hline $\mathrm{x}^{-} ; \mathrm{SD}$ & $\mathrm{x}^{-} ; \mathrm{SD}$ & $\mathrm{x}^{-} ;$SD & $\mathrm{x}^{-} ; \mathrm{SD}$ & $\mathrm{x}^{-} ; \mathrm{SD}$ & $\mathrm{x}^{-} ; \mathrm{SD}$ \\
\hline \multicolumn{5}{|c|}{ Kierownicy } \\
\hline 3,$73 ; 1,09$ & 3,$39 ; 1,43$ & 4,$06 ; 1,23$ & 4,$21 ; 0,81$ & 3,$87 ; 1,24$ & 2,$00 ; 1,28$ \\
\hline \multicolumn{5}{|c|}{ Specjaliści } \\
\hline 3,$89 ; 0,90$ & 3,$49 ; 1,34$ & 3,$80 ; 1,09$ & 3,$78 ; 0,95$ & 4,$14 ; 0,91$ & 2,$76 ; 1,13$ \\
\hline \multicolumn{7}{|c|}{ Wykonawcy } \\
\hline 3,$74 ; 1,02$ & 3,$40 ; 1,31$ & 3,$42 ; 1,13$ & 3,$47 ; 1,10$ & 3,$77 ; 1,02$ & 2,$98 ; 1,27$ \\
\hline
\end{tabular}

$\mathrm{x}^{-}$- średnia; SD - odchylenie standardowe; w przypadku stresu skala jest odwrócona

Źródło: opracowanie własne.

Średnie zmiennych samopoczucie oraz równowaga pomiędzy pracą a życiem osobistym są najwyższe na stanowisku specjalistycznym, a najmniejsze - na stanowisku kierowniczym. Najwyższą satysfakcję z pracy zadeklarowali kierownicy. Wskaźnik kontroli jest najbardziej nasilony u kierowników, którzy mają największy zakres obowiązków i z zasady realizują najbardziej odpowiedzialne zadania. Warunki pracy są najbardziej satysfakcjonujące dla specjalistów, a najmniej - dla wykonawców. Jeśli chodzi o stres w pracy, to grupa ostatnia, czyli wykonawców, zmaga się z nim w najwyższym stopniu, natomiast kierowniczki odczuwają go najmniej. 
Pobrane z czasopisma Annales H - Oeconomia http://oeconomia.annales.umcs.pl Data: 26/04/2023 15:43:40

DOBROSTAN I SATYSFAKCJA Z JAKOŚCI ŻYCIA ZAWODOWEGO MŁODYCH KOBIET...

Tabela 3. Wskaźniki przy uwzględnieniu dzietności

\begin{tabular}{|c|c|c|c|c|c|}
\hline Dobrostan & Równowaga praca-życie & Satysfakcja z pracy, kariery & Kontrola & Warunki pracy & Stres (R) \\
\hline $\mathrm{x}^{-} ; \mathrm{SD}$ & $\mathrm{x}^{-} ; \mathrm{SD}$ & $\mathrm{x}^{-} ; \mathrm{SD}$ & $\mathrm{x}^{-} ; \mathrm{SD}$ & $\mathrm{x}^{-} ; \mathrm{SD}$ & $\mathrm{x}^{-} ; \mathrm{SD}$ \\
\hline \multicolumn{5}{|c|}{ Kobiety posiadające dzieci } \\
\hline 3,$93 ; 0,98$ & 3,$39 ; 1,35$ & 3,$36 ; 1,15$ & 3,$51 ; 1,17$ & 3,$78 ; 1,13$ & 2,$90 ; 1,28$ \\
\hline \multicolumn{5}{|c|}{ Kobiety nieposiadające dzieci } \\
\hline 3,$80 ; 0,98$ & 3,$23 ; 1,32$ & 3,$63 ; 1,14$ & 3,$75 ; 0,90$ & 4,$12 ; 0,92$ & 2,$82 ; 1,21$ \\
\hline
\end{tabular}

$\mathrm{x}^{-}$- średnia; SD - odchylenie standardowe; w przypadku stresu skala jest odwrócona

Źródło: opracowanie własne.

Kobiety, które posiadają dzieci, miały lepsze ogólne samopoczucie, jednak odczuwały większy stres związany z pracą niż kobiety bezdzietne. Co ciekawe, kobiety, które mają potomstwo, zadeklarowały większą kontrolę pomiędzy pracą a życiem osobistym (poziom istotności p-value $=0,7$ ). Większą satysfakcję z pracy oraz kariery przejawiają z kolei respondentki nieposiadające dzieci ( $p$-value $=0,7)$. Kontrola w pracy została gorzej oceniona przez kobiety nieposiadające dzieci. Również wskaźnik warunków pracy przychylniej oceniły kobiety, które nie są matkami. W tym przypadku różnica między obiema grupami jest zauważalna (średnia 4,12 do 3,78).

\section{Dyskusja wyników i wnioski}

Przebadana grupa respondentek przejawia średnie zadowolenie z życia zawodowego. Jak wskazują Easton i Van Laar (2018), satysfakcja z życia zawodowego jest związana z wykonywanym zawodem. Najpierw ci badacze testowali narzędzie W grupie akademików brytyjskich, gdzie zaobserwowali niską satysfakcję z życia zawodowego. Podobne wnioski dotyczą polskich akademików (Rakowska, 2020). Badane kobiety mają lepsze samopoczucie niż akademicy. Respondentki, które wzięły udział w opisanym badaniu, odczuwają także mniejszą kontrolę nad równowagą pomiędzy pracą a życiem osobistym. Gorzej wypada kontrola w pracy, ponieważ została oceniona na poziomie 3,63 (średnia), podczas gdy akademicy uzyskali średnią 3,16. Zmienna dotycząca stresu występującego w miejscu pracy jest wyższa aż o 1,00 w stosunku do osób zatrudnionych na uczelniach wyższych. Wskaźniki lepiej ocenione przez młode respondentki to satysfakcja z pracy oraz warunki pracy.

Ograniczeniem opisanych badań jest niereprezentatywność próby badawczej oraz jej mała wielkość. W przyszłości warto dokonać szerszej i głębszej analizy związanej z poprawą satysfakcji z życia zawodowego młodych kobiet, które zostając matkami, mogą mieć problem z odnalezieniem się w nowej roli oraz z pogodzeniem jej z pracą zawodową. Istotny może okazać się także wykonywany zawód. W jednym miejscu zatrudnienia jakość pracy i satysfakcja z nią związana są wyższe, w innych zaś są niższe. W wyniku przeprowadzenia analizy może się okazać, które branże są bardziej przychylne dla kobiet. Być może te o specyfice typowo męskiej przyczynią się do uzyskania wyższych wskaźników. 


\section{Bibliografia}

Bańka, A. (2000). Psychologia organizacji. W: J. Strelau (red.), Psychologia. Podręcznik akademicki (T. 3; s. 321-350). Gdańsk: GWP.

Carlson, D.S., Kacmar, K.M., Wayne, J.H., \& Grzywacz, J.G. (2006). Measuring the positive side of the work-family interface: Development and validation of a work-family enrichment scale. Journal of Vocational Behavior, 68(1). doi:10.1016/j.jvb.2005.02.002

Diener, E., Emmons, R.A., Larsen, R.J., \& Griffin, S. (1985). The Satisfaction with Life Scale. Journal of Personality Assessment, 49(1). doi:10.1207/s15327752jpa4901_13

Drzeżdżon, W. (2006). Wartości pracy wśród młodzieży szkół zawodowych. Tczew: Bernardinum.

Easton, S.A., \& Van Laar, D.L. (2012). User Manual for the Work-Related Quality of Life (WRQoL) Scale: A Measure of Quality of Working Life. Portsmouth: University of Portsmouth.

Easton, S.A., \& Van Laar, D.L. (2014). User Manual for the Work-Related Quality of Life (WRQoL) Scale: A Measure of Quality of Working Life. Portsmouth: University of Portsmouth.

Easton, S.A., \& Van Laar, D.L. (2018). User Manual for the Work-Related Quality of Life (WRQoL) Scale: A Measure of Quality of Working Life. Portsmouth: University of Portsmouth.

Friedman, S.D., \& Greenhaus, J.H. (2000). Work and Family - Allies or Enemies?: What Happens When Business Professionals Confront Life Choices. Oxford: Oxford University Press.

Hildt-Ciupińska, K. (2014). Work-life balance a wiek pracowników. Bezpieczeństwo Pracy: nauka i praktyka, (10).

Kanter, R.M. (1977). Some Effects of Proportions on Group Life. W: P.P. Rieker, E. Carmen (eds.), The Gender Gap in Psychotherapy (s. 53-78). Boston: Springer.

Karaś, D., \& Cieciuch, J. (2017). Polska adaptacja Kwestionariusza Dobrostanu (Psychological Well-Being Scales) Caroll Ryff. Roczniki Psychologiczne, 20(4). doi:10.18290/rpsych.2017.20.4-4pl

Krause, A., Żyta, A., \& Nosarzewska, S. (2010). Normalizacja środowiska społecznego osób z niepetnosprawnościa intelektualna. Toruń: Wydawnictwo Edukacyjne Akapit.

Kreiner, G.E., Hollensbe, E.C., \& Sheep, M.L. (2009). Balancing borders and bridges: Negotiating the work-home interface via boundary work tactics. Academy of Management Journal, 52(4). doi:10.5465/amj.2009.43669916

Major, D.A., Morganson, V.J., \& Bolen, H.M. (2013). Predictors of Occupational and Organizational Commitment in Information Technology: Exploring Gender Differences and Similarities. Journal of Business and Psychology, 28. doi:10.1007/s10869-012-9282-5

Mendryk, I., \& Rakowska, A. (2016). Wpływ postrzeganego wsparcia organizacji na poziom zadowolenia z pracy i dobrostan pracowników w różnym wieku: wyniki badań. Przedsiębiorczość i Zarządzanie, $17(2 / 3)$.

Niśkiewicz, Z. (2016). Dobrostan psychiczny i jego rola w życiu człowieka. Studia Krytyczne, 3.

Rakowska, A. (2020). Jakość życia zawodowego nauczycieli akademickich - wyniki badań pilotażowych. W: A. Krejner-Nowecka, J. Cewińska (red.), Zarzadzanie kapitatem ludzkim-wyzwania (s. 263-277). Warszawa: Oficyna Wydawnicza SGH.

Rakowska, A., \& Cichorzewska, M. (2019). Rola wartości preferowanych przez pracowników w kontekście kształtowania inkluzywnych organizacji. Przedsiębiorczość i Zarządzanie, 20(6/3).

Schor, J.B. (1991). Global equity and environmental crisis: an argument for reducing working hours in the north. World Development, 19(1). doi:10.1016/0305-750X(91)90039-K

Smoder, A. (2012). Elastyczne formy pracy jako instrument work-life balance. Polityka Spoleczna, 39(1). WHO. (1948). WHO's Definition of Health: Philosophical Analysis.

Wołowska, A. (2013). Satysfakcja z pracy i jej wyznaczniki a poczucie jakości życia urzędników. Rocznik Andragogiczny, 20. doi:10.12775/RA.2013.006

Worrall, L., \& Cooper, C.L. (2006). The Quality of Working Life: Managers' Health and Well-being. Executive Report. Chartered Management Institute. 